\title{
CSK Gene
}

National Cancer Institute

\section{Source}

National Cancer Institute. CSK Gene. NCI Thesaurus. Code C20123.

This gene is involved in signal transduction and intercellular adhesion. 